\title{
Not Everyone Has (the) Balls: Urban Exploration and the Persistence of Masculinist Geography
}

\author{
Carrie Mott \\ Department of Geography, University of Kentucky, Lexington, KY, USA; \\ carrie.mott@uky.edu \\ Susan M. Roberts \\ University of Kentucky; Department of Geography, University of Turku, Finland; \\ sueroberts@uky.edu
}

\begin{abstract}
In geographic scholarship, urban exploration (urbex) has been examined as an embodied practice with radical potential for re-appropriating urban spaces. However, geographic literature on urban exploration has largely ignored the particular qualities of the urban explorer as a subject and neglected feminist scholarship on embodiment and social difference. Based on our examination of both popular and academic treatments of urbex we identify a prevalent and largely unacknowledged culture of masculinism. We ask: Whose bodies explore? What counts as experience? What constitutes the exchange between body and place? And, with what effects? Addressing these questions permits considerations of exclusions and marginalizations left unaddressed in much geographic literature on urbex.
\end{abstract}

Keywords: urban exploration, urbex, feminism, masculinism, embodiment, difference

\section{Introduction}

Urban exploration, urbex, or UE, is an increasingly popular pastime, enjoyed by many people around the world. In an essay entitled 'Confessions of an urban explorer', explorer and photographer Troy Paiva explains:

Urbex means different things to different people. For some, it's about infiltrating a city's storm drains and subway tunnels. For others, it's climbing bridges and radio towers. Generally speaking, though, Urbex is the exploration of TOADS (Temporary, Obsolete, Abandoned and Derelict Spaces). Industrial complexes, military installations, junkyards, asylums, hotels-you name it (2008:9).

While some urban explorers travel alone, many go exploring in pairs or groups, often going out after dark. Enthusiasts are linked through numerous online forums and, for many urbexers, an integral part of the practice is sharing their writings and photographic documentation of their explorations. The actual term 'Urban exploration' dates from the 1990s and is usually credited to renowned practitioner Jim Chapman, aka Ninjalicious. Ninjalicious started the zine Infiltration: The Zine About Going Places You're Not Supposed to Go (http://www.infiltration.org) in 1996. This and other early zines (including Jinx Magazine: http://www.jinxmagazine.com) were circulated among networks of dispersed urban explorers that expanded 
throughout the 1990s and into the 2000s as more people picked up the hobby. Similar to the development of other activities that began more or less as youth subcultures, such as skateboarding, graffiti, and raves, urban exploration has grown to become a widespread and more recognized leisure activity (High and Lewis 2007). Urban exploration has also been highlighted through a wide range of popular media-including newspapers (eg Barkham 2012; Feuer 2010; Gibberd 2007; Godwin 2012; Jurgensen 2001; Simon 2003), websites (eg 28 Days Later: http:// www.28dayslater.co.uk/forums/; Sleepycity: http://www.sleepycity.net; UER Forum: http://www.uer.ca/forum), and film, most notably Urban Explorers: Into the Darkness, a documentary released in 2007, and Urban Explorer, a horror movie from 2011. As it has become more popular, the practice and meanings of urbex also have attracted considerable attention from scholars.

Not surprisingly, considering our discipline's longstanding interest in exploration, landscapes, cities, and the meanings of place, urban exploration has drawn the attention of geographers who have documented and examined aspects of the practice. In this paper we examine this geographical literature. We find that urban exploration has been approached in a variety of ways, highlighting variously: the experiential, psychogeographical, and sensorial experiences of the explorer-subject; the embodied nature of urban exploration and its meanings; practices of documentation and representation; and the political significance of the practice. An emphasis on the embodied explorer-subject in both popular representations and scholarly urbex literature leads us to ask: Whose bodies explore? What counts as experience? What constitutes the exchange between body and place? And, with what effects? To address these questions, we consider the ways that conceptualizations of differently embodied subjects could more directly inform critical urbex scholarship. We show first that insights developed by feminist scholars and others regarding embodiment could significantly enrichen scholarship on urbex. We then turn to self-representations by urbexers themselves, noting the prevalence of a highly masculinized explorer-subject and we reflect on why, with one recent exception (Bennett 2012), this subject has gone largely unexamined in academic treatments of urban exploration. In the concluding section we offer some ideas about how geographical research on urban exploration could proceed along lines that more fully recognize the significance of differentially embodied lives for diverse subjects' engagements with urban space, and with one another.

\section{Geographers and Urbex}

In 2005 David Pinder published a paper entitled 'Arts of urban exploration' that introduced a theme issue of Cultural Geographies. Pinder's paper and those that comprised the special issue focused on artistic interventions in public spaces aimed at engendering a fresh emphasis on experiencing and opening urban space. Pinder considered several events created by artists in terms of their efforts to "transgress boundaries between art and everyday space, to explore the street and public realm through artistic practice" (2005:387; see also Bonnett 1992) and raised some issues about the meaning of these practices through a consideration of "urban psychogeography". A term taken from Guy Debord, psychogeography encompasses "the study of the precise laws and specific effects of the geographical environment, 
consciously organized or not, on the emotions and behavior of individuals" (Debord 2006 [1955]:8). Psychogeography has recently enjoyed something of an intellectual revival through the work of writers and modern-day flâneurs such as London-based lain Sinclair and Will Self whose reflections of walking across the grain of urban and suburban space have held some interest for geographers (see for example Bonnett 2009; Pile 2002, 2005). The stress on interior emotions and on individual behavior is a hallmark of Debord's definition, of the work of the psychogeography writers, and of much of the geographical literature on urban exploration (Bennett 2011a; Garrett 2010, 2011a, 2011b, 2011c, 2012a).

Of course, not all urbexers are invested in exploring as psychogeographic experiments of either a political or literary bent, but are more focused on issues of memory. Luke Bennett, for example, has researched urbexers interested in abandoned military installations and has found that for "bunkerologists" the emphasis is on documenting and cataloging the structures they explore, recording their attributes in straightforward ways albeit with a "reverential and memorialist tone" (Bennett 2011a:424). Bennett's research emphasizes that for these urbexers, experiencing and exploring the sites are just elements in a set of practices which include their online interactions and efforts at documentation and recording. Holly Prescott $(2009,2011)$ approaches the practice from a feminist perspective, and considers the meaningfulness of images and documentation to memory. She discusses the different ways that women explore ruined maternity wards, not in person, but through information posted by urban explorers and circulated through Facebook. The women in Prescott's study are able to explore through their interaction with the images and information posted and recall stories of the births of their children while dialoging with one another online. Though her work is not much cited in geographical literature on urbex, Prescott's research shows how the use of photographs resulting from urban exploration can contribute to the "commemoration" of otherwise lost memories through "focusing upon UE's deconstruction of the hierarchies of spatial experience and power, and by emphasizing its re-imagination of the ways in which institutional spaces are memorialized" (Prescott 2009:107).

For many urbexers, the creation of a visual record of their explorations through photography and video is a significant part of what they do. For some, the purpose may be primarily documentary (as in Bennett's 2011a case study), while for other urbexers, the appeal of the TOADS (Temporary, Obsolete, Abandoned, and Derelict Spaces) lies in their distinctive visual aesthetic and the technical challenges of capturing complex and often dark scenes with a camera. The cultural significance of an "aesthetics of decay" recognized and valorized by many urbexers also has been noted by Caitlin DeSilvey among other scholars (DeSilvey 2006; see also DeLyser 2004; Pinder 2005; Trigg 2006). Indeed, there is now a whole genre of photography, much of it contributed by urbexers, known as "ruin porn" (Greco 2012). The wrecked spaces of Detroit have been a particular focus for such photographic stylists (Leary 2011). The label "porn" while it may be intended to be dismissive, does raise issues of the consumption of these photographs and of the images' deferral of deeper questions concerning exactly how and why it is that Detroit has so many ruins in the first place, similar to the way that consumers of porn do not generally concern themselves with questions of its production. Some argue that 
urbexer's photography has more to do with documenting first-hand experiences and thus establishing credibility among the urbex community than with any aesthetics of decay. As Bradley Garrett has written: "[u]rban exploration is not about aesthetics of decay (Trigg 2006), it's about experiencing the world in the here and now" (2011b, emphasis added). Documenting their own travels and experiences through photography is likely a major motivation for many urbexers. However, in reviewing the geographical literature, we did not come across any sustained critical treatment of the range of visual images produced by urban explorers, despite their ubiquity and apparent significance to the practice.

Geographers have been very interested in the politics of urban exploration. For example, Garrett writes of urban exploration as "place hacking"-the title of his PhD thesis and former blog (http://www.placehacking.co.uk/). He writes: "This social practice, which sizzles with subversivness, resembles the work of computer hackers (Löwgren 2000) except that urban explorers are largely hack [sic] places rather than virtual systems. Both are elective procedures of participation in otherwise closed objects (proprietary cyberspace or off-limits architecture)" (Garrett 2012a:14). Martin Dodge and Rob Kitchin (2006) similarly analyzed urban exploration in terms of "space hacking" in a 2006 conference paper. Seeing urbex as a form of hacking alludes to the perception that the practice holds potential to challenge "hegemonic spatial control" (Garrett 2012a:29-30). Bennett, however, argues that for some urban explorers their activities are more like hobbies without any articulated political agenda, beyond a commitment to memorializing sites (Bennett 2011b). Bennett's argument along these lines drew a response from Garrett who claimed that Bennett unfairly generalized his findings to damn all urbex "as a naïve representational practice tinged with nostalgic fetishism" (Garrett 2011b), a charge Bennett forcefully refuted (Bennett $2011 b)$. Suffice it to say that urbex is a slippery label encompassing a vast array of different activities and communities and for which there is no single understanding of the political import (or lack thereof) of urbex.

Nonetheless, geographers analyzing urbex have occasionally aligned contemporary urban exploration with previous calls for urban expeditions, often those of Bill Bunge (Garrett 2012a:29-30; Pinder 2005:388). In fact, urbex has little in common with Bunge's explicit concerns for a socially just city. As Andrew Merrifield pointed out, "Bunge retained the label 'expedition' in an attempt to subvert the exploration practices of the nineteenth century" (1995:54), a claim echoed by some urbex analysts (Garrett 2012a; Pinder 2005). However, Bunge's expeditions were designed to be "contributive" (in Merrifield 1995:54) and collaborative, driven by the agendas of ordinary urban citizens. Ironically, while today's urbex geographers tend to share Bunge's insistence on rejecting "contented 'campus geography" (quoted in Merrifield 1995:53) and to valorize physically being out in the "field", there is a preference for places that are devoid of other human beings (at least those who are not fellow urbexers). For Bunge, the point of getting out into the city was to work with ordinary people and understand their views and needs. Though urbex may trace some connections to Bunge's project, the similarities are quite superficial, and the differences very revealing. The politics of urbex, and of urbex in geography, appear to be more gestural than direct. We return to this point later, when we argue that the prevalent stress on the individual embodied experiences of urban 
explorers themselves seems to steer urbex and its analysts away from any broader social analysis and critique, and away from any politics of urban social justice of the sort created and practiced by Bunge and his collaborators.

Many urban explorers are less interested in experimenting with the experience of the street or other public spaces as part of a productive political intervention (Pinder 2005), and are more concerned with going into spaces that are in one way or another off limits to regular pedestrians, describing urbex as infiltration (eg Paiva 2008) and likening their activities to recreational trespassing (Garrett 2012a). Emphasizing the attraction of more marginalized and hidden spaces within the city, such as "the unadorned backsides of the city, the alleys, culverts, service areas, and other microspaces, along with wastelands, railway sidings, spaces behind billboards, and unofficial rubbish tips" (Edensor 2005:833), Tim Edensor has investigated the ways that such spaces, being comparatively free of "intensive performative and aesthetic regulation", are sites where official urban stories about the past and about the meaning of the city are disrupted. As Edensor puts it, there is "[a] far more multiple, nebulous, and imaginative sense of memory [that] persists in these undervalued, undercoded, mundane spaces, critiquing the discursive closure upon the mnemonic meanings of other sites" (2005:833-834). More recently, Garrett has picked up on this theme, highlighting the individuated experiential aspect of urbex: "[u]rban exploration is a practice through which individuals take the opportunity to create memories of places that can sit alongside, or at times even undermine, official histories, creating a symbiotic exchange between body and place" (2011a:1052).

For Edensor, the physical exploration of abandoned industrial sites or ruins is particularly interesting in this regard. For him, such spaces being "full of random juxtapositions, clutter, obstacles, and numerous pathways ... demand a fuller performative, corporeal engagement with space and hence with memory" (2005:834). Edensor investigates the "sensual interactions" between the body and the ruin and the ways in which ruins offer alternative experiences in mobility and memory (see also Pile 2002). In reflecting on his own explorations of abandoned asylums, Garrett explains: "We go to these places to attempt to read the inscriptions, to have bodily encounters which challenge or reconfigure our conception of everyday experience and to eventually begin writing ourselves into places by photographing them/ourselves in them" (2011a:1062). The stress on embodied encounters and their unscripted nature, for Edensor, Garrett and others, distinguishes urbexers from tourists. As Garrett (2012d) writes, "exploration is not something you do, it's who you are", pointing to an understanding of urbex as something deeper than an occasional leisure activity such as tourism. Urbex is constructed instead in terms of identity, specifically of an explorer-subject who possesses some essential qualities as such. Nonetheless, some have pointed out connections between urbex and "adventure tourism" (Fraser 2012) and "dark tourism". Dark tourism focuses on haunted sites of "death, disaster, and atrocity", including those associated with war (Lennon and Foley 2000:3), and such sites are of interest to some in the urbex world, though urbexers would typically seek out the abandoned and off-limits sites and explicitly avoid any organized tourist attraction where memory is officially scripted. 
While the scholarly literature on urban exploration is diverse and often selfreflective, it is the experiential embodied character of urban exploration emphasized by many geographers who study it that we examine. We ask: Whose bodies? What counts as experience? What constitutes the exchange between body and place? And, with what effects? These questions are prompted by our observations that geographic literature on urban exploration largely mirrors dominant presentations of exploring bodies found in wider popular urbex discourses. Specifically, we are struck by the authority granted particular exploring bodies: those performing an able-bodied, heteronormative and typically white masculinity. Further, we are puzzled by the muted treatment of social difference and differentiated bodies in the geographic literature on urbex. We find this especially surprising given the longstanding work of feminist geographers, among others, on the relationship between exploration and geography, on gender and urban space, and on the explorer-subject in the production of geographical knowledge.

\section{Exploring Bodies: What Counts as Experience?}

Feminist scholarship on earlier periods of exploration has drawn attention to the ways in which the explorer-subject was associated with ideals of rugged masculinity, and also to its wider implication in sociospatial processes undergirded by patriarchy, racism and heteronormativity (Domosh 1991, 1997; Maddrell 2008, 2009; Morin 2008; Pratt 1992). Further, geographical research on embodiment offers several approaches to the differentiated body and its relationship with space and place. In particular, feminist geographers have shown how embodied differences can be conceptualized in non- or anti-essentialist ways and how differentiated embodied subjects can be considered in their spatial contexts (eg Colls 2007, 2012; Longhurst 1995, 2001; Nast and Pile 1998; Simonsen 2000). Within geographical scholarship on urban exploration, there has been minimal consideration of these issues; a situation that indicates to us that, for this body of literature within geography, it appears still to be the case that "feminism remains outside the project" (Rose 1993:3). Accordingly, our critique aims to bridge the gulf between geographic treatment of urbex and feminist scholarship on exploration and embodiment. Through such an approach, we strive to contribute to the possibilities of bringing urban exploration literature's treatment of embodied experience into closer dialogue with research dedicated to "theorizing and researching ... differentiated subjects" and their bodies (Colls 2012:433).

The politics of urbex are not singular or coherent, as we have seen. Nonetheless, discussion of the political potential of urban exploration by some geographers has tended to see the practice as opening "the potential for radical subjectivity" and as a novel mode of appropriating urban space (Garrett 2012a:17). In bringing feminist insights about differentially embodied subjects together with the geographical literature on urban exploration we show how a supposedly progressive politics founded on embodied experiential encounters with hidden urban spaces founders on its failure to recognize difference. In an examination of some popular urbex materials, we find that there are widespread (though far from universal) discourses that emphasize masculinity, fearlessness and physical strength, reinforcing older 
ideas about what sorts of bodies belong to explorer-subjects, and ignoring the exclusions they enact. Ultimately, we find a paradox where, on one hand, urbex emphasizes embodiment and progressive politics, while on the other, there appears to be a reluctance to consider different kinds of bodies and the inclusions/exclusions perpetuated through practices and discourses of exploration and the privileged explorer-subject. As long as this paradox remains unexamined, possibilities for a radical engagement with the city through urbex will inevitably fall short.

Geography's historical relationship to exploration and thus to empire has been subject to much critique and disciplinary self-reflection (Driver 2001, 2005; Livingstone, 1992; Morin 2011; Pratt 1992; Rose 1993). The possible relevance of these critiques of geography's role in imperial and colonial projects to current urban exploration has been acknowledged in passing by some geographers (eg Garrett 2010:1449), though without meaningful consideration of their implications for contemporary urbex research and practice. Sometimes, as we mentioned above, urban exploration is connected with Bunge's project, although most often this is not the case. The lack of engagement with critiques of exploration and empire that highlight the way such practices work through racialized and gendered domination tends to leave unexamined questions about how "exploration" is still associated with the privileged body of the explorer-subject.

Some have noted issues raised by the character of the embodied exploring subject (Pinder 2005; Prescott 2009, 2011; Bennett 2012). But, by and large, geographical scholarship on urbex has not questioned the power of the archetypal explorer inherited from history: a white, able-bodied, risk-taking man who, with "stout boots and a stout heart", can go where more frail and less well equipped others dare not venture (Domosh 1997). A major lesson of postcolonial and feminist investigations into our discipline's history has been that the ways in which geographical knowledge is produced, stabilized, and authorized are understood to rest on social relations built upon and co-constitutive of social differences and inequalities.

Embodiment is a topic that has been of interest to geographers for some time and initially emerged in opposition to dominant discourses of an abstract universalized subject who was implicitly male, white, able-bodied, and heterosexual (Massey 1991). For example, Longhurst points out that "there is ... no one body-the body is a masculinist illusion. There are only bodies in the plural" (1995:98). Situating the inherent plurality of embodiment in spatial terms, Nast and Pile note that places are embodied simply because "this is how we live our lives- through places, through the body" (1998:1). There is then, no universal subject, no singular explorersubject. Rather, in contrast to the narrow notion that only particular practices constitute embodied exploration, all practices of exploration are necessarily embodied, regardless of the degree of physicality involved.

Geographic scholarship offers a range of perspectives on how embodied subjects are "simultaneously situated and differentiated according class, race, ethnicity, gender and age" (Colls 2012:434). For example, Holt (2004) considers the ways that disabled elementary school children are socially marked as different from their peers in otherwise "inclusive" classrooms. Hansen and Philo (2007) discuss the "impaired body" and the ways in which the visual appearance of differently abled bodies often 
results in their being regarded as less than fully human. More important than the visuality of impairment is the (in)ability of particular bodies to move and perform in standard ways. As Imrie and Edwards (2007) show, there is much recent geographic scholarship oriented around the embodiment of disability, particularly as it relates to children, the elderly, and disabilities less readily identified from outside, as with challenges in learning, behavior, or mental health.

Deeper acknowledgement of individually differentiated bodies in urban exploration research provides a way to bring about considerations of a more socially just city, particularly in terms of what constitutes authentic participation in the practice. Colls (2012:434), calling on Braidotti (1994), gestures to the idea of a "nomadic feminism" which offers a way to develop "an account of a differentiated subject that is multiple in its constitution and location." This idea of the multiplicity of subjectivity can help us think productively about both the different ways that people explore, as well as the different bodies who perform the action. For example, Prescott's $(2009,2011)$ work with mothers viewing abandoned maternity wards online shows how individual mothers are explorers who simultaneously experience memories of the birthing process, the phenomenon of urban decay, as well as moments of communion with other mothers and the urban explorers who posted the original photos. While the mothers were not physically present in the abandoned maternity wards, their experience is no less real.

In a post on his former blog, Place Hacking, Garrett (2012b) explained that he was interested not in "why we explore, but why everyone else has stopped exploring". While we do not agree that "everyone else has stopped exploring", much feminist scholarship speaks to the reasons why some might hesitate to engage in urbex practices, and explains that the understanding of "exploration" is highly variable, subject to the particularities of identity and place. As Bondi and Rose (2003) and others point out, there has been extensive work by feminists exploring the question of women's fear in urban environs (see also Day 2001; Pain 1997; Valentine 1989). Indeed, women are often constructed as "doubly victimized, in the sense of being constrained not only by fear but also by the apparent irrationality of this fear" (Bondi and Rose 2003:233). There is first the uncomfortable sensual experience of fear itself, and second, the highly gendered treatment of such reactions as unreasonable. For many women, dark, derelict urban environs signal the dangers of sexual harassment or assault. Urban space, perhaps most especially the type of space favored by urban explorers, simply is not open or accessible in the same ways to all. Wandering in drains and sewers and trespassing on construction sites at night are activities that do not have the same meanings and risks for everyone. The declaration that "no person, or physical barrier, can stop you from going where you want to go and doing what you want to do-the choice is always yours" (Garrett 2012a:7), simply does not hold for many people. Such an attitude is not equally available to everyone. In previous examinations of another urban wandering subject-the flâneur-it has been noted that "[u]ntil women enjoy the same choices as men to act as the flâneur in contemporary cities, gender inequalities in rights to the city will persist" (Preston and Ustundag 2005:221).

The celebratory understanding of urbex as a liberatory venture that everyone should participate in raises important questions about the politics of difference 
and inequality inherent within urbex and in terms of rights to the city. Does a hesitation to bring upon oneself the threat of sexual harassment indicate weakness? What does it mean that some people may not have the physical strength or ability to carry out the activities advocated by urban explorers? Urbex literature advocates an authenticity that comes with the bodily experience of the explorer-subject reminiscent of older derisions of "armchair geography", emphasizing "the difference between reading about the George Washington Bridge and climbing it" (Garrett 2011 b, citing Deyo and Leibowitz 2003). What does such an understanding say about people who are not able, due to the specificities of identity and place, to climb the bridge?

It is not difficult to see how urban exploration could contribute to a sense of personal autonomy and liberation. Wouldn't everyone like to venture wherever they pleased, without fear for personal safety? Ultimately, however, participation in urbex is not simply a choice that everyone is equally enabled to make. While there has been some acknowledgement of this in academic literature on urbex (High and Lewis 2007; Garrett 2012a), discourses of urban exploration, like older discourses of exploration in geography, clearly privilege particular bodies and spatial engagements while discounting others.

Karen Morin highlights the specific type of masculinity understood as requisite for explorers in the late nineteenth century-that of "a 'hard body' [which] embodied strength, fortitude, and glorified athleticism that endured extreme hardship, and in fact thrived on adventure, daring, and danger" (Morin 2008:908). Further, she shows that a narration of this virility was crucial to emphasizing the manliness of early explorers. The scholarly literature on urban exploration has not really examined the extent to which the ideal exploring body may implicitly be similarly specified. More generally, not attending to subjects' difference, to different bodies and their unique personal relations with urban space (and with other bodies), seems to have led to a situation where again the idea of a universal subject is assumed, "with blithe unintentionality, in the shape of a white Western male heterosexual" as Doreen Massey (1991:39) once put it so nicely.

In fact, as feminists and others have pointed out, the ways that social differences are embodied profoundly shape our interactions with space, creating power-geometries that serve to restrict the movements of some while enabling others (Massey 1993). Exploring cities in novel ways may offer opportunities for exciting adventure and play for some (Garrett 2012a; Mould 2009; Pinder 2005). For others, such practices might bring up well founded fears of physical difficulty, harassment, or assault. Hyndman points out that "conditions of highly restricted mobility ... are more common for those bodies that are criminalized, displaced, and/or construed as a security threat to the state and its citizenry" (Hyndman 2004a:171; see also Hyndman 2004b). It might be possible for self-proclaimed urban explorers to avoid arrest due to their privileged identities. However, others may have valid reasons not to expose themselves to such a risk. Eluding security guards and police may prove an entertaining game for some, while for others the risks of such practices are far too great. A person already under surveillance and scrutiny and subject to racial or other forms of profiling by security agencies, for example, faces a much greater risk of harassment and detention than the typical white urban explorer. Heightened security 
in the face of concern with "terrorist threats" in cities around the world only sharpens the risks to particularly racialized people who might reasonably expect to find it harder to persuade the police that they are 'not up to mischief' when they are caught popping up from a manhole cover on a Paris sidewalk (an event recounted in Garrett 2009, 2011c).

The daring of the exploring subject features prominently in self-representation of urban explorers and of urbex practice on popular websites and in web forums. In the next section of the paper, we examine salient features of such representations and note that a significant proportion of urban exploration appears to be oriented around very masculinized (sub)cultures. In many self-representations there is, for example, emphasis on the physical strength and virility of participants, paired in many cases with celebrations of drinking culture and sometimes displays of nudity (eg Actionsquad: http://www.actionsquad.org/; Garrett 2011a, 2011c, 2012a; UER Forum). In making this observation, we once again wish to be clear that we are not arguing that all urbexers are masculinist. We know this is a diverse and contradictory set of engagements with urban space, but have found that among the diversity present in the self-representations of urban explorers, a highly masculinized explorer-subject is very common. Further, with the exception of a recent contribution from Luke Bennett (2012), this salient explorer-subject has gone more or less unremarked by scholars interested in urbex.

\section{Hyper-Masculine Urban Explorers}

You'll hurt, you'll bleed, you may find yourself crouched in an [sic] tunnel alcove nose to the third rail as a subway train whistles past, leaving you wondering how you ended up here. For what? Knowing you had the balls to take life by the balls and live it (Sleepycity: http://sleepycity.net/faqs).

In examining several websites dedicated to urbex we encountered a number of highly gendered tropes reminiscent of the much-critiqued discourse of early geographic explorers. Some urban explorers routinely describe themselves as "penetrating" places often characterized as "virgin" (eg Actionsquad; Sleepycity). In some usages this language denotes accessing places that appear to have been undisturbed by human visitors for some time (Garrett 2012a). For example, an urbex group called Minneapolis Urban Adventurers (MUA) regales visitors to their website with their exploration into the abandoned Ford Assembly Plant in St Paul (Actionsquad). They describe the process through which the plant was abandoned as one in which it "slowly became a born-again virgin" (see http://www. actionsquad.org/fordll1.html). The plant is referred to with feminine pronouns and, as the reader comes to the end of the webpage, a link called "penetration" introduces the part of the story where the MUA gains access to the plant.

Another group of urban explorers we ran across call themselves Operation Penetration. Their website includes photographs and text detailing their explorations of a number of sites between 2000 and 2004. In answering a FAQ, "who are you?" Operation Penetration leaders provide brief bios. One is described thus, 
"BIOKILLER's main concern is penetration, almost to the point of obcession [sic] ... if there is a door, he will open it, if there is a hole, he will penetrate it" (http://www. nofuture.com/op/op.htm). The banner at the top of the page depicts a woman lying in a seductive pose, her body partially obscured by a sheet or blanket, next to the word "penetration" in bold black lettering. On either side of her are photographs of caution and danger signs. ${ }^{1}$

In much the same way, we have found pervasive references in several online urbex communities to a highly masculinized sense of strength, virility, and risktaking, an identity which is reinforced through tales of adventure and proven through photographs and video. More troubling, however, are the ways that these allusions to masculine strength and virility appear through specific references to male genitalia. Garrett, in a post detailing his urban explorations in Barcelona on Sleepycity, explains that at one point he and his companions were ridiculed for not having "balls". Garrett writes, "[h]is suggestion we lacked balls confused us greatly, as those who go head to head with the rolling stock in the grimy, dimly lit, alcoveless metro tunnels are usually not short on testicular fortitude, figuratively speaking" (Garrett 2012c). While this may be "figurative" wording, typical of "exaggerated forms of masculinized language and behavior" observable in many settings (McDowell 2010:653), it is also always more than that. And as such, it reinforces the standard masculinism that characterizes many aspects of urbex.

Self-presentations by urban explorers appear to be very important elements of the practice. Stories of adventures, self-portraits of themselves exploring, or conquering some particularly challenging aspect of the exploration are common on urbex websites and blogs in ways that are often quite stylized. Some urban explorers dress in costume for their sorties. Jinx members, for example, favored evening wear (Deyo and Leibowitz 2003), while other urbex groups prefer more of a soldier or mercenary look with camouflage, black boots, gas masks. Perhaps most typical is an ordinary global north metropolitan grungy look, though with deliberately selected functional footwear and accessories-especially cameras. No matter the attire, for many urbexers, recording themselves exploring appears to be very important and there is much emphasis on visual self-presentation. Urbex websites and blogs are replete with images of urbexers posing on ladders, inside tunnels or abandoned corridors and so on. They are invariably in a conquering or heroic mode. ${ }^{2}$

Some images are reminiscent of the mountain climber atop the summit, while others appear to reference movie stills (invoking, variously, the spy thriller, the action movie, the horror movie), music videos, or video game imagery. In one blog post we found, urbex provided an opportunity for an explicitly pornographic staging. A post on Sleepycity titled "The Pimp Twist" details an incident in which several urban explorers who described themselves as "pimps" posed with a naked woman whom they apparently took on a subterranean photography session (http:// sleepycity.net/posts/71/The-Pimp-Twist). ${ }^{3}$ We are not claiming that this kind of behavior or imagery is typical of the wider urbex community. Certainly, there are plenty of urbexers whose photography is more about atmospheric landscapes or the arcane details of found artifacts, for example. Nonetheless, within urbex there appears to be a pervasive masculinism that creates a fertile breeding ground for eruptions of sophomoric crudity and misogynist imagery, a phenomenon that, to 
our knowledge, remains largely unaddressed within geographic scholarship on the practice.

While many women do engage in urbex, they figure often in photographic representations of the practice as minority figures who appear to be going along with an activity that is largely led and defined by the male explorers (see also Bennett 2012). Bennett's work on bunkerology supports this point. He notes that, while the practice is certainly one that includes women, the "vast majority" of observable participants are male (Bennett 2012:2). Urban explorers may forward the idea that there is nothing "explicit" that denies female participation in urbex groups and that any masculinism is surely "unintentional" (Garrett 2012a:19, 29), even while explaining that one must have the proper "testicular fortitude" to explore (Garrett 2012c). Thus, other ways of exploring and being in the world are marginalized and, in many instances, it seems that urbex remains another heteronormatively masculinized and male-dominated social practice defining the space of the city.

Perhaps all this is not surprising. After all, it is not only urbex websites that contain disturbing representations. Many online forums and enthusiast group websites unrelated to urbex give voice to members whose views could be considered insensitive or even hostile to persons marked by a whole host of differences. And, we should point out that within the urbex materials we examined, we did find instances of discussions about appropriate and inappropriate behavior on the part of explorers, and there were a few cases where urbexers pushed back against eruptions of sexism by their fellow explorers (eg UER Forum). All of this may just be the quite ordinary dynamics of social networks on the web. What is surprising and what is notable is that these characteristics of urbex, understood as more than just the exploring subject in the moment of exploration, have gone almost completely unremarked upon in the geographical literature (Bennett 2012 being the single exception we are aware of). One could argue that this may be a result of a selfconscious distancing on the part of scholars from these "rogue" elements. Nonetheless, these expressions cry out for critical analysis-perhaps as extreme examples, but perhaps also as logical expressions of a pervasive masculinity within certain urbex groups.

\section{Reflections and Conclusions}

In general the treatment of urbex in geography has tended to mirror some of the troubling characteristics of urban exploration itself. We wonder how it is that most analysts of urbex have felt it is sufficient simply to note in passing the deeply gendered and exclusionary nature of the practice, and avoid any sustained or meaningful critique or engagement with extensive relevant feminist literature pertinent to the topic. It seems to us that this might be because the majority of geographers interested in urbex seem, for the most part, to accept the highly individualized, masculinist approach adopted by many urbexers themselves. This is a troubling situation, and one not without irony.

One ironic aspect is that while urbexers appear to have very much taken to heart the lessons of post-positivist knowledge creation that feminists were central in making the case for, they have ended up promoting a highly masculinized 
knowledge-producing subject (see also Colls 2012). While those reflecting on urban exploration would likely agree that "[t]he world is an intersubjective creation" (England 1994:81), and may not be interested in promoting their knowledge as impartial or completely objective, their claims to knowledge are based on an authority and authenticity deriving from a highly masculinized and exclusionary individual experience of exploration, as we show above.

A second irony resides in the fact that feminists were among those who first stressed how bodies matter in our understandings of space and place. Certainly, urbex literature tends to put the body front and center. It is a particular body though, implicitly one with "balls", and the social privileges and entitlements carried by this particular body are too often left unexamined. It is not surprising perhaps that making the body or embodied experiences central to geography does not necessarily avoid a masculinist narrative, particularly when feminist literatures addressing bodies, embodiment, and social difference are largely ignored. We do not all have "balls", and it is important to remember that the ways one goes about exploring are determined by, among other things, our unique personal identities, histories, and associations with place. An emphasis on an archetypal explorersubject serves to marginalize and exclude through an understanding of legitimacy as belonging only to particular bodies and embodied experiences.

Third, emphasis on the individuated nature of urbex experiences-even though the practice appears to be most often carried out in pairs or small groups-permits larger questions about social relations, social differences, exclusions, inequalities and injustices in our cities to be avoided. As Heidi Nast and Steve Pile put it, "[t] he ways in which we live out body/place relationships are political" (1998:2). This fundamental insight that shaped early work on the body and space/place appears to have been forgotten. There are multiple layers of political implications thrown up by even the most cursory journey into the world of urbex.

Our intention is to make the case that there is scope for thorough critical geographic assessments of urban exploration. Consider, first, the possibilities for a psychoanalytical critique. Such a project could learn from analyses of the attraction/ repulsion of spaces such as wetlands, bogs, and marshes, for example (Giblett 1992, 1996). Analyses of how the dark, dank, smelly, slimy attributes of such liminal spaces are emphasized by those who explore them, and of how such spaces conjure "horror" for "patriarchal consciousness" might provide a starting point for understanding the activities of urban explorers, at least those in underground spaces (Giblett 1996:7). Practitioners of urbex are not wholly unaware of the possibilities of psychoanalytic critique. A post on the Minneapolis Urban Adventurers' website, for example, briefly considers the possibility that their interest in exploring dark, wet places is rooted in some deeper psycho-sexual dynamics (Actionsquad). In the scholarly literature, Bennett (2012) offers the most sustained analysis along these lines, while Garrett has gestured towards understanding urban exploration in terms of broader psychoanalytic approaches (eg 2010:1458).

A second potential route for a critical assessment of urbex might draw upon scholarship on disabilities and space (eg Dorn 1998; Gleeson 2000; Imrie and Edwards 2007). Here, we can imagine analyses that take seriously Gleeson's exhortation that "geographers must participate in the political struggle against 
the socio-spatial formations that oppress impaired people" (2000:67) as they consider the practices and experiences of urban mobility present in urban exploration.

Third, urban exploration could be queered, for example, through critical deconstructions of the social boundaries (between us and them; explorers and non-explorers) the practice builds up, or through an investigation of the ways heterosexuality in a context of often quite intense homosociality (the camaraderie of the risk-taking explorers) can get shored up and undermined simultaneously (Bennett 2012).

A fourth possible angle for a critical analysis could take class as central, considering, for example, the very different reasons for being in abandoned spaces on the parts of recreational urban explorers and other persons they sometimes encounter or see traces of, persons who are often seeking shelter and a safe place to sleep in cities that increasingly marginalize their presence in public space. A political economy of urban spaces could shed light on how the very different qualities of mobility and encounter that urbex brings into relief can be seen in relation to each other, as elements of the capitalist city in crisis.

These are just suggestive. There are a myriad other possible paths that could be taken to analyze and critically situate the urbex phenomenon, paths that could lead us further by taking seriously the deeply masculinist character of the explorersubject represented in some urbex discourses alongside urbex's tendency to marginalize variously Othered bodies.

\section{Acknowledgments}

Many thanks to the anonymous reviewers whose comments and suggestions greatly improved this paper. Thanks also to Lisa Cliggett, Michele Flippo-Bolduc, Vanessa Marquez, Heidi Nast, Derek Ruez, and Anna Secor who each gave valuable feedback on an early draft of the paper. The paper grew from lively discussions that took place in the University of Kentucky's Committee on Social Theory's Spring 2012 seminar and lecture series on "Security".

\section{Endnotes}

1 See Operation Penetration's banner at http://www.nofuture.com/op/op.htm

2 See http://talkurbex.com/2012/07/wet-smelly-culvert-lightpainting-fun/ for an example of a typical urban explorer self-portrait.

3 In an early draft of this paper, we included an image from the "Pimp Twist" as an example. Upon some reflection, we decided not to reproduce the image. Instead, readers may examine the story and the images themselves on the Sleepy City website: http://sleepycity.net/posts/71/ The-Pimp-Twist, or by contacting the authors.

\section{References}

Barkham P (2012) The illicit art of urban exploration. The Guardian. http://www.guardian. co.uk/uk/shortcuts/2012/apr/09/urban-exploration-student-shard-urbex?intcmp=239 (last accessed 10 July 2012)

Bennett L (2011a) Bunkerology: A case study in the theory and practice of urban exploration. Environment and Planning D: Society and Space 29(3):421-434

Bennett L (2011b) Exploring the bunker: A response to "Shallow Excavation". (last accessed 10 July 2012)

Bennett $L$ (2012) Who goes there? Accounting for gender in the urge to explore abandoned military bunkers. Gender, Place and Culture DOI:10.1080/0966369X.2012.701197 
Bondi $L$ and Rose D (2003) Constructing gender, constructing the urban: A review of Anglo-American feminist urban geography. Gender, Place and Culture 10(3):229-245

Bonnett A (1992) Art, ideology and everyday space: Subversive tendencies from Dada to postmodernism. Environment and Planning D: Society and Space 10:69-86

Bonnett A (1997) Geography, "race" and whiteness: Invisible traditions and current challenges. Area 29(3):193-199

Braidotti R (1994) Nomadic Subjects. Embodiment and Sexual Difference in Contemporary Feminist Theory. Cambridge: Cambridge University Press

Colls R (2007) Materialising bodily matter: Intra-action and the embodiment of "fat". Geoforum 38:353-365

Colls R (2012) Feminism, bodily difference and non-representational geographies. Transactions of the Institute of British Geographers 37:430-445

Day K (2001) Constructing masculinity and women's fear in public space in Irvine, California. Gender, Place and Culture 8(2):109-127

Debord G (2006 [1955]) Introduction to a critique of urban geography. In K Knabb (ed) Situationist International Anthology (pp 8-11). Berkeley: Bureau of Public Secrets

DeLyser D (2004) Ghost towns. In S Harrison, S Pile and N Thrift (eds) Patterned Ground: Ecologies and Geographies of Nature and Culture (pp 196-198). London: Reaktion

DeSilvey C (2006) Observed decay: Telling stories with mutable things. Journal of Material Culture 11(3):318-338

Deyo L B and Leibowitz D (2003) Invisible Frontier: Exploring the Tunnels, Ruins and Rooftops of Hidden New York. New York: Three Rivers Press

Dodge M and Kitchin R (1, April 2006) "Exposing the secret city: Urban exploration as 'space hacking'." Paper presented at the Association of American Geographers annual meeting, Chicago, IL

Domosh M (1991) Towards a feminist historiography of geography. Transactions of the Institute of British Geographers 16(1):95-104

Domosh M (1997) With "stout boots and a stout heart": Feminist methodology and historical geography. In J-P Jones, H Nast and S Roberts (eds) Thresholds in Feminist Geography (pp 225-240). New York: Rowman and Littlefield

Dorn M (1998) Beyond nomadism: The travel narratives of a "cripple". In H Nast and S Pile (eds) Places Through the Body (pp 183-206). London: Routledge

Driver F (2001) Geography Militant: Cultures of Exploration and Empire. Malden: Blackwell

Driver F (2005) The active life: The explorer as biographical subject. Oxford Dictionary of National Biography. http://www.oxforddnb.com/view/theme/94053 (last accessed 10 July 2012)

Edensor T (2005) Industrial Ruins: Space, Aesthetics, and Materiality. Oxford: Berg

Edensor T (2007a) Social practices, sensual excess, and aesthetic transgression in industrial ruins. In K A Franck and Q Stevens (eds) Loose Space: Possibility and Diversity in Urban Life (pp 234-252). London: Routledge

England K (1994) Getting personal: Reflexivity, positionality, and feminist research. The Professional Geographer 46(1):80-89

Feuer A (2010) The wilderness below your feet. New York Times. http://www.nytimes.com/2011/ 01/02/nyregion/02underground.html?pagewanted=all\&_r=0 (last accessed 4 April 2013)

Fraser E (2012) Urban exploration as adventure tourism: Journeying beyond the everyday. In $\mathrm{H}$ Andrews and L Roberts (eds) Liminal Landscapes: Travel, Experience, and Spaces In-between (pp 136-151). New York: Routledge

Garrett B (2009) Paris Catacombs. http://www.placehacking.co.uk/2009/07/09/ paris-catacombs-july-2009/ (last accessed 11 February 2013)

Garrett B (2010) Urban explorers: Quests for myth, mystery, and meaning. Geography Compass 4(10):1448-1461

Garrett B (2011a) Assaying history: Creating temporal junctions through urban exploration. Environment and Planning D: Society and Space 29(6):1048-1067

Garrett B (2011b) Shallow excavation: A response to "Bunkerology". http://societyandspace. com/2011/06/10/shallow-excavation-a-response-to-bunkerology-by-bradley-l-garrett/ (last accessed 11 February 2013) 
Garrett B (2011c) Cracking the Paris Carrières: Corporal terror and illicit encounter under the city of light. ACME: An International E-Journal for Critical Geographies 10(2): 269-277

Garrett B (2012a) "Place Hacking: Tales of Urban Exploration." Unpublished PhD thesis, Royal Holloway University of London

Garrett B (2012b) The adventurers club. http://www.placehacking.co.uk/2012/05/28/ adventurers-club/ (last accessed 11 February 2013)

Garrett B (2012c) Barcelona nights. http://sleepycity.net/posts/275/Barcelona-Nights (last accessed 1 February 2013)

Garrett B (2012d) Convergence, transmission, and storage. http://www.placehacking.co.uk/ 2012/11/15/finalpost/ (last accessed 11 February 2013)

Gibberd B (2007) Children of darkness. New York Times. http://www.nytimes.com/2007/07/ 29/nyregion/thecity/29shad.html?pagewanted=all (last accessed 10 July 2012)

Giblett R (1992) Philosophy (and sociology) in the wetlands: The s(sub)lime and the uncanny. New Formations 16:142-159

Giblett R (1996) Postmodern Wetlands: Culture, History, Ecology. Vancouver: University of British Columbia Press

Gleeson B (2000) Enabling geography: Exploring a new political-ethical ideal. Ethics, Place and Environment 3(1):65-69

Godwin R (2012) On a mission with London's urban explorers. London Evening Standard. http://www.standard.co.uk/lifestyle/esmagazine/on-a-mission-with-londons-urban-explorers7851504.html (last accessed 10 July 2012)

Greco J (2012) The psychology of ruin porn. Atlantic Cities. http://www.theatlanticcities.com/ design/2012/01/psychology-ruin-porn/886/ (last accessed 3 April 2013)

Hansen N and Philo C (2007) The normality of doing things differently: Bodies, spaces and disability geography. Tidjschrift voor Economische en Sociale Geografie 98(4):493-506

High S and Lewis D (2007) Corporate Wasteland: The Landscape and Memory of Deindustrialization. Ithaca: Cornell University Press

Holt L (2004) Children with mind-body differences and performing (dis)ability in classroom micro-spaces. Children's Geographies 2(2):219-236

Hyndman J (2004a) The (geo)politics of gendered mobility. In L A Staeheli, E Kofman and L J Peake (eds) Mapping Women, Making Politics (pp 169-184). New York: Routledge

Hyndman J (2004b) Mind the gap: Bridging feminist and political geography through geopolitics. Political Geography 23(3):307-322

Imrie R and Edwards C (2007) The geographies of disability: Reflections on the development of a sub-discipline. Geography Compass 1(3):623-640

Jurgensen J (2001) Urban explorers are picture of stealth. Los Angeles Times. http://articles. latimes.com/2001/may/20/news/mn-223 (last accessed 10 July 2012)

Leary J P (2011) Detroitism. Guernica: A Magazine of Art and Politics. http://www. guernicamag.com/features/leary_1_15_11/ (last accessed 3 April 2013)

Lennon J and Foley M (2000) Dark Tourism. New York: Continuum

Livingstone D (1992) The Geographical Tradition. Malden: Blackwell

Longhurst R (1995) The body and geography. Gender, Place and Culture 2(1):97-106

Longhurst R (2001) Bodies: Exploring Fluid Boundaries. London: Routledge

Löwgren J (2000) Origins of hacker culture(s). zone.k3.mah.se/k3jolo/HackerCultures/origins. htm (last accessed 4 February 2013)

Maddrell A (2008) The "map girls": British women geographers' war work, shifting gender boundaries, and reflections on the history of geography. Transactions of the Institute of British Geographers 33(1):127-148

Maddrell A (2009) Complex Locations: Women's Geographical Work in the UK, 1850-1970. Malden: Wiley

Massey D (1991) Flexible sexism. Environment and Planning D: Society and Space 9(1):31-57

Massey D (1993) Power-geometry and a progressive sense of place. In J Bird, B Curtis, T Putnam, G Robertson and L Tickner (eds) Mapping the Futures: Local Cultures, Global Change (pp 60-70). London: Routledge 
McDowell L (2010) Capital culture revisited: Sex, testosterone, and the city. International Journal of Urban and Regional Research 34(3):652-658

Merrifield A (1995) Situated knowledge through exploration: Reflections on Bunge's geographical expeditions. Antipode 27(1):49-70

Morin K (2008) Charles P. Daly's gendered geography, 1860-1890. Annals of the Association of American Geographers 98(4):897-919

Morin K (2011) Civic Discipline: Geography in America, 1860-1890. Burlington: Ashgate

Mould O (2009) Parkour, the city, the event. Environment and Planning D: Society and Space 27:730-750

Nast H and Pile S (1998) Places Through the Body. New York: Routledge

Pain R (1997) Social geographies of women's fear of crime. Transactions of the Institute of British Geographers 22(2):231-244

Paiva T (2008) Confessions of an urban explorer. In id. Night Vision: The Art of Urban Exploration (pp 8-13). San Francisco: Chronicle

Pile S (2002) Memory and the city. In J Campbell and J Harbord (eds) Temporalities: Autobiography and Everyday Life (pp 111-127). Manchester: Manchester University Press

Pile S (2005) Real Cities: Modernity, Space, and the Phantasmagorias of City Life. Thousand Oaks: Sage

Pinder D (2005) Arts of urban exploration. Cultural Geographies 12(4):383-411

Pratt M L (1992) Imperial Eyes: Travel Writing and Transculturation. London: Routledge

Prescott H (2009) Birth-place. Feminist Review 93(1):101-108

Prescott H (2011) Reclaiming ruins: Childbirth, ruination, and urban exploration photography of the ruined maternity ward. Women's Studies Quarterly 39(3/4):113-132

Preston V and Ustundag E (2005) Feminist geographies of the "city": Multiple voices and multiple meanings. In L Nelson and J Seager (eds) Companion to Feminist Geography (pp 211-227). Malden: Blackwell

Rose G (1993) Feminism and Geography: The Limits of Geographical Knowledge. Cambridge: Polity

Simon S (2003) Detroit artifacts are unearthed by urban explorers. Chicago Tribune. http:// articles.chicagotribune.com/2003-07-06/business/0307060128_1_detroit-explorer-josh-kahlurban-exploration-league (last accessed 7 July 2010)

Simonsen K (2000) The body as battlefield. Transactions of the Institute of British Geographers 25(1):7-9

Trigg D (2006) The Aesthetics of Decay: Nothingness, Nostaligia, and the Absence of Reason. New York: Peter Lang

Valentine G (1989) The geography of women's fear. Area 21(4):385-390 